\title{
Influence of Anthropogenic Pollution on the Abundance Dynamics of Some Freshwater Invertebrates in the Coastal Area of Cameroon
}

\author{
E. Koji ${ }^{1,2}$, O. V. Noah Ewoti' ${ }^{1}$ F. M. Onana ${ }^{3}$, S. Tchakonté1, C. Lontsi Djimeli' ${ }^{1}$, A. Tamsa Arfao ${ }^{1,4}$, \\ G. Bricheux ${ }^{5}$, T. Sime-Ngando5, M. Nola ${ }^{1 *}$ \\ ${ }^{1}$ Laboratory of Hydrobiology and Environment, Faculty of Sciences, University of Yaounde 1, Yaounde, Cameroon \\ ${ }^{2}$ Department of Animal Biology and Physiology, Faculty of Sciences, University of Douala, Douala, Cameroon \\ ${ }^{3}$ Department of Aquatic Ecosystems Management, Institute of Fisheries and Aquatic Sciences, University of Douala, Douala, \\ Cameroon \\ ${ }^{4}$ Microbiology and Biotechnology Laboratory, Saint Jerome Polytechnic Institute, Saint Jerome Catholic University of Douala, \\ Douala, Cameroon \\ ${ }^{5}$ Université Clermont Auvergne, Campus Universitaire des Cézeaux, Aubière, France \\ Email: *moise.nola@yahoo.com
}

How to cite this paper: Koji, E., Noah Ewoti, O.V., Onana, F.M., Tchakonté, S., Lontsi Djimeli, C., Tamsa Arfao, A., Bricheux, G., Sime-Ngando, T. and Nola, M. (2017) Influence of Anthropogenic Pollution on the Abundance Dynamics of Some Freshwater Invertebrates in the Coastal Area of Cameroon. Journal of Environmental Protection, 8, 810-829.

https://doi.org/10.4236/jep.2017.87051

Received: May 24, 2017

Accepted: June 27, 2017

Published: June 30, 2017

Copyright $\odot 2017$ by authors and Scientific Research Publishing Inc. This work is licensed under the Creative Commons Attribution International License (CC BY 4.0).

http://creativecommons.org/licenses/by/4.0/ (c) (i) Open Access

\begin{abstract}
The abundance dynamic of some freshwater invertebrates in relation with the abiotic factors of the medium was studied from March 2013 to March 2014 on the main streams of the Wouri and Sanaga basins. Individuals of Copepoda, Atyidae, Chironomidae and Physidae were collected, identified and counted. Samplings were carried out monthly; meanwhile measurements of the environmental variables were taken. Results of the physico-chemical analyses revealed that water of the Sanaga basin is globally well oxygenated (77\% - 92\%) and faintly mineralized $(14-107 \mu \mathrm{S} / \mathrm{cm})$, excepted in the stations receiving household pollutants. Inversely, in the Wouri basin, waters are hypoxic with high content of organic matters $(27.79 \pm 9.43 \mathrm{mg} / \mathrm{L})$. During rainy season (June-September), there is a dilution-dispersion of the organic matter due to stormwaters. Concerning biological analyses, the families of Physidae and Chironomidae were more abundant in urban stations than in stations situated in suburban area, especially during low water level period, showing that they are well adapted to anthropogenic and organic pollutions. The hypoxic conditions of urban waterways do not favor the proliferation of sensitive taxa such as Atyidae and Copepoda. These taxa preferred well oxygenated waters with rapid flow, and are more abundant during rainy season in stations located in suburban area or which are less subjected to anthropogenic disturbances.
\end{abstract}

\section{Keywords}

Floods, Anthropogenic Pollution, Dilution-Dispersion, Invertebrates, 


\section{Introduction}

The preservation and the rehabilitation of the ecological quality of surface waters in sub-Saharan Africa is one of the major stakes for the environmental, touristic and socio-economic sustainability. It is thus a necessity to carry out regular environmental monitoring of surface waters, using reliable and relevant indicators. The use of biological indicators associated with the physicochemical analyses constitutes one of the most informative and complete method for the water quality assessment. At this purpose, freshwater macroinvertebrates are broadly regarded as particularly sensitive indicators of the health of urban waterway ecosystems subject to anthropogenic activities [1] [2] [3]. Indeed, as an important functional group in stream ecosystems, macroinvertebrates show predictable responses since they are sensitive indicators of long-term environmental changes in water and habitat quality [4] [5] [6]. They are thus used in surface water assessment and monitoring [7] [8].

The physid individuals and chironomid larvae are well adapted to live in extremely polluted aquatic media [9] [10]. Indeed, their ecological diversity is favor by their physiological adaptation to the high variability of the environmental factors of the medium such as salinity, acidity, the high thermal amplitudes and the dissolved oxygen fall [11]. Inversely freshwater shrimps of the family Atyidae preferred well oxygenated and low mineralized water, and are mostly abundant in the upstream and middle stream [12] [13]. Copepods are also sensitive to water pollution and to the variations of the environmental conditions of the medium [14] [15]. Consequently, it becomes obvious that the abundance dynamics of aquatic invertebrates is controlled by various parameters of the medium, which also show spatial and temporal variations. This study aims to determine the influence of anthropogenic activities through the abiotic factors of the medium on the abundance dynamic of some freshwater invertebrates in the coastal region of Cameroon.

\section{Materials and Methods}

\subsection{Study Area and Sampling Sites}

The littoral region of Cameroon is located between $3^{\circ} 30^{\prime}$ and $3^{\circ} 58^{\prime}$ of latitude North and $11^{\circ} 20^{\prime}$ and $11^{\circ} 40^{\prime}$ of longitude East. The climate is of two seasons, including a long rainy season from March to November, with rainfall generally ranging between $4000 \mathrm{~mm}$ and $5000 \mathrm{~mm}$ per year; and a short dry season from December to February [16]. The average monthly temperatures reach $28.5^{\circ} \mathrm{C}$ for the hottest month and $24.6^{\circ} \mathrm{C}$ for the coldest and soils have an acidic $\mathrm{pH}$ [16] [17]. The main rivers of the region (Wouri, Sanaga and Dibamba) are used mainly for hydro energy power generation, fishing and transportation of goods and people. Salinity and pollutants are transported from either side during tides. 
Activities such as deforestation, installation and functioning conditions of the hydroelectric dam have a strong anthropogenic pressure on the river from the town of Edea [18].

The samples were collected monthly, from March 2013 to March 2014 between 8 am and $12 \mathrm{am}$. A total of 16 sampling stations were selected in the basins of Wouri and Sanaga, respectively in the cities of Douala and Edea (Table 1). Eight stations were chosen in three streams of the lower Sanaga basin (Mabandi, Boué and Sanaga), and eight other stations located in seven streams in the Wouri basin (Kondi, Longmayagui, Mboppi, Mgoua, Tongo-Bassa, Mbanya and Wouri).

\subsection{Measurement of Environmental Variables}

The measurements of physicochemical parameters of water at each sampling station were done following standard methods [19] [20]. Water temperature $\left({ }^{\circ} \mathrm{C}\right)(\mathrm{WT}), \mathrm{pH}$, and dissolved oxygen (\%)(DO) were measured in situ using an alcohol thermometer, a HACH HQ11d pH-meter, and a HACH HQ14d oxymeter, respectively. Likewise, electrical conductivity $(\mu \mathrm{S} / \mathrm{cm}$ ) (Cond) and salinity (\%o) (Sal) were measured in situ using a HACH HQ 14d conductimeter. Current

Table 1. Description of the physical environment of the study sites.

\begin{tabular}{|c|c|c|c|c|c|c|}
\hline \multirow{2}{*}{ Basin } & \multirow{2}{*}{ Stream } & \multirow{2}{*}{ Station } & \multicolumn{3}{|c|}{ Geographic coordinate } & \multirow[t]{2}{*}{ Characteristics of the sampling station } \\
\hline & & & Altitude (m) & Latitude & Longitude & \\
\hline \multirow{7}{*}{ Wouri } & Kondi & $\mathrm{KO}$ & 7 & $04^{\circ} 04^{\prime} 05.9^{\prime \prime} \mathrm{N}$ & $09^{\circ} 45^{\prime} 13.9^{\prime \prime} \mathrm{E}$ & Marshy zone receiving urban wastes \\
\hline & Longmayagui & $\mathrm{LM}$ & 22 & $04^{\circ} 00^{\prime} 29.4^{\prime \prime} \mathrm{N}$ & $09^{\circ} 45^{\prime} 00.4^{\prime \prime} \mathrm{E}$ & Marshy zone receiving urban wastes \\
\hline & Mboppi & MP & 4 & $04^{\circ} 02^{\prime} 41.0^{\prime \prime} \mathrm{N}$ & $09^{\circ} 42^{\prime} 43.8^{\prime \prime} \mathrm{E}$ & Marshy zone receiving household, urban and industrials wastes \\
\hline & Mgoua & MG & 22 & $04^{\circ} 01^{\prime} 19.6^{\prime \prime} \mathrm{N}$ & $09^{\circ} 42^{\prime} 22.4^{\prime \prime} \mathrm{E}$ & Receptacle of urban and industrials wastes \\
\hline & \multirow{2}{*}{ Tongo-bassa } & TW & 6 & $04^{\circ} 05^{\prime} 06.3^{\prime \prime} \mathrm{N}$ & $09^{\circ} 43^{\prime} 22.9^{\prime \prime} \mathrm{E}$ & $\begin{array}{l}\text { Receptacle of urban and industrials wastes } \\
\text { This station also received salty water from the Wouri }\end{array}$ \\
\hline & & TB & 9 & $04^{\circ} 03^{\prime} 44.2^{\prime \prime} \mathrm{N}$ & $09^{\circ} 43^{\prime} 14.3^{\prime \prime} \mathrm{E}$ & $\begin{array}{l}\text { Receptacle of urban wastes and industrials wastewater from } \\
\text { SIC CACAO }\end{array}$ \\
\hline & Wouri & WO & -5 & $04^{\circ} 04^{\prime} 20.3^{\prime \prime} \mathrm{N}$ & $09^{\circ} 42^{\prime} 08.6^{\prime \prime} \mathrm{E}$ & Receptacle of urbanwastes Traditional fishing \\
\hline \multirow{7}{*}{ Sanaga } & \multirow{3}{*}{ Mabandi } & M1 & 36 & $03^{\circ} 47^{\prime} 12.4^{\prime \prime} \mathrm{N}$ & $10^{\circ} 07^{\prime} 33.2^{\prime \prime} \mathrm{E}$ & $\begin{array}{l}\text { Rural area with no house in a } 300-\mathrm{m} \text { radius around the } \\
\text { sampling station, no industrial activities }\end{array}$ \\
\hline & & M2 & 17 & $03^{\circ} 47^{\prime} 58.1^{\prime \prime} \mathrm{N}$ & $10^{\circ} 07^{\prime} 21.5^{\prime \prime} \mathrm{E}$ & Receptacle of urban and industrials wastes \\
\hline & & M3 & 13 & $03^{\circ} 48^{\prime} 10.4^{\prime \prime} \mathrm{N}$ & $10^{\circ} 07^{\prime} 24.0^{\prime \prime} \mathrm{E}$ & Receptacle of urban and industrials wastes \\
\hline & \multirow{3}{*}{ Boue } & B1 & 65 & $03^{\circ} 46^{\prime} 46.0^{\prime \prime} \mathrm{N}$ & $10^{\circ} 08^{\prime} 09.0^{\prime \prime} \mathrm{E}$ & $\begin{array}{l}\text { Rural area with no house in a } 500-\mathrm{m} \text { radius around the } \\
\text { sampling station }\end{array}$ \\
\hline & & B2 & 44 & $03^{\circ} 47^{\prime} 27.0^{\prime \prime} \mathrm{N}$ & $10^{\circ} 07^{\prime} 59.2^{\prime \prime} \mathrm{E}$ & $\begin{array}{l}\text { Rural area with no house in a } 200-\mathrm{m} \text { radius around the } \\
\text { sampling station }\end{array}$ \\
\hline & & B3 & 40 & $03^{\circ} 47^{\prime} 39.3^{\prime \prime} \mathrm{N}$ & $10^{\circ} 07^{\prime} 58.7^{\prime \prime} \mathrm{E}$ & Confluence zone with the Sanaga river Lack of riparian vegetation \\
\hline & Sanaga & $\mathrm{S} 2$ & 12 & $03^{\circ} 48^{\prime} 12.4^{\prime \prime} \mathrm{N}$ & $10^{\circ} 07^{\prime} 24.2^{\prime \prime} \mathrm{E}$ & Lack of riparian vegetation, high rate of flow \\
\hline
\end{tabular}


velocity $(\mathrm{CV})$ was measured by timing the front of a neutral non-pollutant dye (blue of methylene) over a known distance along the station. Suspended solids (SS) (mg/L), turbidity (NTU) and color (Pt-Co) were measured in the laboratory using $\mathrm{HACH} \mathrm{DR} / 2800$ spectrophotometer. Dissolved carbon dioxide $\left(\mathrm{DCO}_{2}\right)$ $(\mathrm{mg} / \mathrm{L})$ and organic matter (Oxy) (mg/L) were determined by volumetric method. Monthly rainfall $(\mathrm{mm})$ (Rain), air temperature (AT) $\left({ }^{\circ} \mathrm{C}\right)$, insolation $\left(\mathrm{Kwh} / \mathrm{m}^{2} /\right.$ day) (Insol) and the relative wetness (\%) (Hum) data for the study period were collected at the Douala Airport Meteorological Research Station.

\subsection{Sampling and Identification of Aquatic Invertebrates}

For the sampling of copepod individuals at each studied station, $60 \mathrm{~L}$ of water were filtered through a plankton sieve $(10 \mathrm{~cm}$ diameter and $64 \mu \mathrm{m}$ mesh size). For this purpose, subsamples of water were collected mainly under aquatic macrophytes using a $10 \mathrm{~L}$ bucket. Materials collected in the sieve were then preserved into a glass sampling bottles with $4 \%$ formalin. In the laboratory, all individuals of each sample were identified under stereomicroscope and optic microscope with the use of appropriate taxonomic keys [21] [22] and counted. The abundances were expressed as number of individuals per liter (Ind./L).

Concerning macroinvertebrates, samples were collected at each station using a long-handled kick net $(30 \mathrm{~cm} \times 30 \mathrm{~cm}$ side, $400 \mu \mathrm{m}$ mesh-size, $50 \mathrm{~cm}$ depth). For each station, samplings were done in a $100 \mathrm{~m}$ stretch following protocol described by Stark et al. [23]. At each station, 20 drags of the kick net were done in different micro-habitat, each corresponding to a surface of $0.15 \mathrm{~m}^{2}(30 \mathrm{~cm} \times 50$ $\mathrm{cm})$. The materials that were collected in the sampling net were rinsed through a $400 \mu \mathrm{m}$ sieve bucket and all macroinvertebrate individuals were sorted and preserved in plastics sampling bottles with $70 \%$ ethanol. In the laboratory, all aquatic insects belonging to the families Atyidae (Decapoda), Chironomidae (Diptera) and Physidae (Gasteropoda) were identified under a stereomicroscope using appropriate taxonomic keys [24] [25], and counted. The density was expressed as number of individuals per square meter (ind. $/ \mathrm{m}^{2}$ ).

\subsection{Data Analyses}

The ANOVA tests followed by post-hoc tests were used to Banferroni pairwise comparisons for quantitative data. T-student test was used to compare the samples in pairs. A logarithmic transformation was performed prior to the matrix of quantitative variables to ensure compliance with normality hypothesis. The Principal Component Analysis was used to search the relationship between abiotic and biological variables. The method of classification by the K-means clusters was used to divide the study period according to the weather variables. XLSTAT.2014 software was used for all analyses.

\section{Results}

\subsection{Environmental Variables}

The mean values and standard deviation (SD) of environmental variables meas- 
ured at each sampling station are shown in Table 2. In the watershed of Sanaga, the maximum value of water temperature $\left(31.5^{\circ} \mathrm{C}\right)$ was observed in station S2 during the month of January. In the Wouri basin, the values of water temperature varied between $25^{\circ} \mathrm{C}(\mathrm{KO})$ and $34^{\circ} \mathrm{C}(\mathrm{MG})$, respectively during the months of July and May. The t-student test revealed that, mean value of water temperature registered in the Wouri basin $\left(29.06^{\circ} \mathrm{C} \pm 1.99^{\circ} \mathrm{C}\right)$ was significantly $(\mathrm{P}<$ $0.05)$ higher than the mean value obtained in the Sanaga basin $\left(27.21^{\circ} \mathrm{C} \pm\right.$ $\left.2.11^{\circ} \mathrm{C}\right)$. In Edea, the highest values of the suspended solids were obtained at station S2 $(125 \mathrm{mg} / \mathrm{L})$ in September. Whereas the values of suspended solids registered in Douala, fluctuated between $3 \mathrm{mg} / \mathrm{L}$ (July) and $358 \mathrm{mg} / \mathrm{L}$ (June) respectively in stations KB and WO. In the Sanaga basin, the values of turbidity oscillated around an average of $28.66 \pm 26.43 \mathrm{NTU}$, with a maximum value of 144 NTU recorded at S2 station in September.

While in the watershed of Wouri, values of turbidity varied between 11 NTU (TW, June) and 316 (WO, February), with a mean value of $56.85 \pm 55.14$ NTU. This mean value was significantly $(\mathrm{t}$-student test, $\mathrm{P}<0.05)$ higher than the mean value obtained in the Sanaga basin. The values of water color fluctuated between de $27 \mathrm{Pt}-\mathrm{Co}$ (M1) and $776 \mathrm{Pt}-\mathrm{Co}$ (S2), with a mean value of $157.07 \pm 137.81$ $\mathrm{Pt}-\mathrm{Co}$ in Edea, while in Douala, values ranged from $70 \mathrm{Pt}-\mathrm{Co}$ (TB) to $3072 \mathrm{Pt}-\mathrm{Co}$ (WO) with an average value of $363.39 \pm 411.39 \mathrm{Pt}-\mathrm{Co}$. The values of $\mathrm{pH}$ showed a range of 5.50 (M1, February) to 8.20 (S2, March) with a mean value of $7.27 \pm$ 0.50 in Edea. At the level of Douala, $\mathrm{pH}$ values oscillated between 6.30 and 7.70

Table 2. Mean values and standard deviation of abiotic parameters measured at each sampling station during the study period $\left(\mathrm{Oxy}=\right.$ oxydability, $\mathrm{WT}=$ water temperature, $\mathrm{DCO}_{2}=$ dissolved carbon dioxide, $\mathrm{Sal}=$ salinity, Cond $=$ conductivity, $\mathrm{OD}=$ oxygen dissolved, $\mathrm{SS}=$ suspended solids, Turb = turbidity, $\mathrm{CV}=$ water current velocity).

\begin{tabular}{|c|c|c|c|c|c|c|c|c|c|c|c|c|}
\hline Basin & Stations & $\begin{array}{l}\text { Oxy } \\
(\mathrm{mg} /)\end{array}$ & $\begin{array}{l}\text { WT } \\
\left({ }^{\circ} \mathrm{C}\right)\end{array}$ & $\begin{array}{c}\mathrm{DCO}_{2} \\
(\mathrm{mg} / \mathrm{L})\end{array}$ & $\begin{array}{l}\text { Sal } \\
(\% o)\end{array}$ & $\mathrm{pH}$ & $\begin{array}{c}\text { Cond } \\
(\mu \mathrm{S} / \mathrm{cm})\end{array}$ & $\begin{array}{l}\text { OD } \\
(\%)\end{array}$ & $\begin{array}{c}\text { SS } \\
(\mathrm{mg} / \mathrm{L})\end{array}$ & $\begin{array}{c}\text { Turb } \\
\text { (NTU) }\end{array}$ & $\begin{array}{c}\text { Color } \\
\text { (Pt-Co) }\end{array}$ & $\begin{array}{c}\mathrm{CV} \\
(\mathrm{m} / \mathrm{s})\end{array}$ \\
\hline \multirow{7}{*}{ Sanaga } & B1 & $4.2 \pm 1.4$ & $25.4 \pm 0.3$ & $11.3 \pm 2.0$ & $0.01 \pm 0.00$ & $7.4 \pm 0.1$ & $25.1 \pm 5.3$ & $81.4 \pm 2.9$ & $16.8 \pm 4.1$ & $18.9 \pm 2.0$ & $104.6 \pm 10.0$ & $0.98 \pm 0.18$ \\
\hline & B2 & $8.9 \pm 2.4$ & $25.7 \pm 0.3$ & $15.7 \pm 4.7$ & $0.02 \pm 0.00$ & $7.4 \pm 0.2$ & $29.2 \pm 2.1$ & $77.8 \pm 5.0$ & $12.5 \pm 2.1$ & $20.7 \pm 2.0$ & $118.2 \pm 9.3$ & $0.74 \pm 0.11$ \\
\hline & B3 & $7.4 \pm 0.9$ & $26.1 \pm 0.3$ & $12.7 \pm 1.7$ & $0.02 \pm 0.00$ & $7.4 \pm 0.1$ & $29.5 \pm 2.3$ & $79.2 \pm 4.7$ & $12.9 \pm 2.1$ & $23.6 \pm 3.2$ & $141.4 \pm 28.1$ & $0.50 \pm 0.06$ \\
\hline & S2 & $7.8 \pm 0.9$ & $29.4 \pm 0.5$ & $19.8 \pm 3.3$ & $0.04 \pm 0.02$ & $7.3 \pm 0.1$ & $40.5 \pm 5.6$ & $92.2 \pm 3.5$ & $41.8 \pm 8.9$ & $58.2 \pm 11.1$ & $312.0 \pm 62.2$ & $0.01 \pm 0.00$ \\
\hline & M1 & $3.1 \pm 0.9$ & $26.3 \pm 0.4$ & $10.8 \pm 2.4$ & $0.03 \pm 0.01$ & $7.2 \pm 0.2$ & $37.2 \pm 2.3$ & $92.9 \pm 1.6$ & $10.5 \pm 1.7$ & $14.2 \pm 1.7$ & $75.6 \pm 12.1$ & $1.04 \pm 0.19$ \\
\hline & M2 & $13.4 \pm 1.7$ & $28.0 \pm 0.6$ & $22.3 \pm 5.5$ & $0.09 \pm 0.01$ & $7.0 \pm 0.1$ & $204.5 \pm 9.4$ & $55.5 \pm 6.6$ & $11.3 \pm 2.4$ & $18.8 \pm 2.1$ & $126.0 \pm 27.3$ & $0.23 \pm 0.04$ \\
\hline & M3 & $13.7 \pm 2.3$ & $28.5 \pm 0.5$ & $22.7 \pm 5.7$ & $0.08 \pm 0.01$ & $7.2 \pm 0.1$ & $199.2 \pm 11.1$ & $64.3 \pm 5.0$ & $18.8 \pm 3.7$ & $24.3 \pm 5.5$ & $115.5 \pm 9.4$ & $0.11 \pm 0.02$ \\
\hline \multirow{7}{*}{ Wouri } & LM & $15.8 \pm 2.1$ & $29.3 \pm 0.4$ & $33.1 \pm 15.4$ & $0.10 \pm 0.01$ & $7.0 \pm 0.1$ & $283.2 \pm 16.9$ & $31.45 \pm 7.7$ & $50.5 \pm 20.4$ & $50 \pm 18.6$ & $171.1 \pm 16.9$ & $0.10 \pm 0.01$ \\
\hline & WO & $12.38 \pm 1.3$ & $28.9 \pm 0.6$ & $21.7 \pm 5.7$ & $0.30 \pm 0.10$ & $7.3 \pm 0.1$ & $277.7 \pm 137.9$ & $58.7 \pm 6.4$ & $72.5 \pm 26.3$ & $74.2 \pm 23.9$ & $524.4 \pm 223.1$ & $0.13 \pm 0.01$ \\
\hline & MB & $24.4 \pm 2.0$ & $29.5 \pm 0.5$ & $23.2 \pm 2.8$ & $0.20 \pm 0.00$ & $7.1 \pm 0.1$ & $422.8 \pm 33.1$ & $8.7 \pm 1.3$ & $50.4 \pm 10.7$ & $52.7 \pm 8.8$ & $310.1 \pm 49.7$ & $0.20 \pm 0.01$ \\
\hline & MG & $29.4 \pm 1.7$ & $29.7 \pm 0.6$ & $39.0 \pm 13.4$ & $0.30 \pm 0.04$ & $7.2 \pm 0.1$ & $656.2 \pm 72.3$ & $9.8 \pm 2.3$ & $100.3 \pm 21.1$ & $106.5 \pm 19.8$ & $586.7 \pm 112.8$ & $0.30 \pm 0.01$ \\
\hline & MP & $27.9 \pm 1.9$ & $29.1 \pm 0.4$ & $27.7 \pm 3.0$ & $0.25 \pm 0.03$ & $7.2 \pm 0.1$ & $528.9 \pm 37.3$ & $10.6 \pm 2.0$ & $83.2 \pm 20.9$ & $70.4 \pm 11.8$ & $416.8 \pm 72.3$ & $0.32 \pm 0.01$ \\
\hline & TB & $26.9 \pm 1.8$ & $29.3 \pm 0.5$ & $27.7 \pm 4.2$ & $0.20 \pm 0.03$ & $7.0 \pm 0.1$ & $425.5 \pm 24.0$ & $10.3 \pm 1.4$ & $36.5 \pm 5.3$ & $41.5 \pm 6.8$ & $238.2 \pm 34.8$ & $0.30 \pm 0.00$ \\
\hline & TW & $23.6 \pm 3.0$ & $29.2 \pm 0.5$ & $26.8 \pm 6.0$ & $0.26 \pm 0.07$ & $7.1 \pm 0.1$ & $399.5 \pm 30.8$ & $24.2 \pm 5.7$ & $30.1 \pm 4.8$ & $30.6 \pm 4.0$ & $174.8 \pm 19.9$ & $0.14 \pm 0.01$ \\
\hline
\end{tabular}


UC with an average of $7.16 \pm 0.34$

Values of electrical conductivity varied between $14 \mu \mathrm{S} / \mathrm{cm}$ (B1, August) and $548 \mu \mathrm{S} / \mathrm{cm}$ (M3, February) with a mean value of $89.25 \pm 115.81 \mu \mathrm{S} / \mathrm{cm}$ in the Sanaga basin. In the Wouri basin, value of electrical conductivity showed a range of $65-1093 \mu \mathrm{S} / \mathrm{cm}$ at the level of stations WO and MG respectively, with a mean value of $403.84 \pm 203.11 \mu \mathrm{S} / \mathrm{cm}$. In Edea, the high rate of water salinity was obtained at station M2 (0.20\%o), meanwhile in Douala, values fluctuated between $0.04 \%$ (WO, July) and $1.30 \%$ (WO, February), with stations WO (0.52\%o \pm $0.42 \%$ ) and TW $(0.45 \%$ $\pm 0.21 \%$ ) recording highest mean values (Banferroni; $\mathrm{P}<0.05)$. According to t-student test, mean values of water salinity appeared to be significantly higher in Wouri basin $(0.27 \%$ $\pm 0.23 \%$ ) than in Sanaga basin (0.03\% $\pm 0.04 \%$ o).

In Edea, the values of oxydability oscillated between $0.20 \mathrm{mg} / \mathrm{L}$ (M1, November) and $39.65 \mathrm{mg} / \mathrm{L}(\mathrm{M} 3$, February), with stations M2 (18.01 $\pm 10.68 \mathrm{mg} / \mathrm{L})$ and M3 (19.61 $\pm 11.18 \mathrm{mg} / \mathrm{L})$ recording highest mean values. In Douala, values of oxydability fluctuated between $43.75 \mathrm{mg} / \mathrm{L}(\mathrm{MG})$ and $2.96 \mathrm{mg} / \mathrm{L}$ (KO).The t-student test revealed that, mean value of oxydability registered in the Wouri basin $(21.79 \pm 9.43 \mathrm{mg} / \mathrm{L})$ was significantly $(\mathrm{P}<0.05)$ higher than the mean value obtained in the Sanaga basin $(9.20 \pm 8.63 \mathrm{mg} / \mathrm{L})$.

In Edea, dissolved oxygen content oscillated between $22.40 \%$ and $107 \%$ respectively at stations M2 and S2, meanwhile in Douala, values ranged from $1 \%$ (MP) to $104.10 \%(\mathrm{~KB})$. The mean value of dissolved oxygen content registered in Edea $(79.46 \% \pm 19.53 \%)$ is significantly (t-student; $\mathrm{P}<0.05)$ higher than the mean value recorded in Douala $(25.07 \% \pm 26.80 \%)$.Values of dissolved carbon dioxide obtained in Edea oscillated between $1.50 \mathrm{mg} / \mathrm{L}$ (M1, March) and 56.80 $\mathrm{mg} / \mathrm{L}$ (B2, January), while in Douala, values ranged from $7.04 \mathrm{mg} / \mathrm{L}$ (LM) to $52.80 \mathrm{mg} / \mathrm{L}$ (MP) respectively in July and March 2013.

Furthermore, high values of current velocity were obtained in Edea watershed, whereas in Douala, the values of current velocity fluctuated between $0.10 \mathrm{~m} / \mathrm{s}$ (WO) and $1.39 \mathrm{~m} / \mathrm{s}$ (MP). Mean value of current velocity was significantly (t-student; $\mathrm{P}<0.05$ ) high during rainy season and showed positively significant correlation with rainfall $(\mathrm{r}=0.41 ; \mathrm{P}<0.05)$.

Concerning meteorological parameters, the monthly values of insolation varied between $3.35 \mathrm{kWh} / \mathrm{m}^{2} /$ day (August) and $5.36 \mathrm{kWh} / \mathrm{m}^{2} /$ day (February), while values of the air temperature and the relative wetness fluctuated between $24.8^{\circ} \mathrm{C}$ (August) and $28.51^{\circ} \mathrm{C}$ (February), and between $73.9 \%$ (January) and $86.9 \%$ (September), respectively. The monthly maximum values of rainfall were registered in September $(746 \mathrm{~mm})$, while the minimum were recorded in February $(1.4 \mathrm{~mm})$. Positive and significant correlation $(\mathrm{r}=0.78 ; \mathrm{P}<0.05)$ was found between rainfalls and relative wetness.

\subsection{Partitioning of the Study Period Using the K-Means Cluster's Method}

The results of the K-means cluster's classification based on meteorological pa- 
Table 3. Results of the K-means cluster's classification based on meteorological parameters.

\begin{tabular}{cccc}
\hline Cluster & $\mathbf{1}$ & $\mathbf{2}$ & $\mathbf{3}$ \\
\hline Intra-group variance & 7820.07 & 5974.79 & 5258.63 \\
Minimal distance to barycenter & 7.90 & 0.89 & 39.15 \\
Mean distance to barycenter & 66.87 & 59.98 & 55.78 \\
Maximal distance to barycenter & 120.62 & 101.75 & 83.67 \\
& May & December & June \\
Months & April & January & July \\
& August & February & September \\
& October & March & \\
Subdivision & November & & \\
& Low flood & Low water level & Over flood \\
\hline
\end{tabular}

rameters permitted to determine three clusters (Table 3). Cluster 1 regroups the month of May, April, August, October and November. These months are characterized by relatively moderated rainfalls, with an average of $335.5 \mathrm{~mm}$, and a mean value of insolation of $4.23 \mathrm{kWh} / \mathrm{m}^{2} /$ day. These months correspond to low flood. Cluster 2 regroups the month of March, December, January and February which are characterized by very low rainfall $(104.04 \mathrm{~mm})$ and very high values of insolation and air temperature. These months correspond to the period of low water level. Cluster 3 is made up of June, July and September, characterized by high rainfalls (with a monthly mean value of $701.77 \mathrm{~mm}$ ), high value of relative wetness $(85.52 \%)$ and low insolation $\left(3.74 \mathrm{kWh} / \mathrm{m}^{2} /\right.$ day). These months correspond to the over flood period, with high dilution of organic matters.

\subsection{Composition and Distribution of Taxa}

Table 4 presents the species identified in the 4 classes (Malacostraca, Maxillopoda, Insecta and Gasteropoda) of invertebrates studied in the watershed of Sanaga and Wouri during the study period. In addition to the Nauplii and Copepodits larvae that are not easy to identify to species level, 9 species of micro-crustaceans belonging to the family Cyclopidae were identified in the study sites. In the same way, 2 freshwater shrimp species of the family Atyidae, 1 species of the family Chironomidae (Insect-Diptera) and 2 species belonging to the family Physidae (Gasteropoda-Basommatophora) were identified during the study.

A total of 17,555 individuals of Copepoda, 2588 individuals of freshwater shrimps, 5212 individuals of Diptera-Chironomidae and 18,055 individuals of Gasteropoda-Physidae were collected in the two river basins (Sanaga and Wouri) during the study period (Table 4). For freshwater shrimps, Caridina africana was the most represented species with $86.5 \%$ of total abundance, while Caridina nilotica registered just $13.5 \%$ of the total individuals. Physa acuta was largely dominant with $91.4 \%$ of relative abundance against $8.6 \%$ for Aplexa sp. Con- 
Table 4. Summary of abundances (relative abundances) of invertebrate taxa identified in the two watersheds during the study period.

\begin{tabular}{|c|c|c|c|c|}
\hline Classes & Orders & Families & Species & $\begin{array}{c}\text { Abundance (relative } \\
\text { abundances) }\end{array}$ \\
\hline \multirow{11}{*}{ Maxillopoda } & \multirow{11}{*}{ Copepoda } & \multirow{9}{*}{ Cyclopidae } & Mesocyclops sp. & $1315(7.5 \%)$ \\
\hline & & & Allocyclopina sp. & $543(3.1 \%)$ \\
\hline & & & Eucyclops serrulatus & $344(2.0 \%)$ \\
\hline & & & Thermocyclops $s p$. & $183(1.0 \%)$ \\
\hline & & & Tropocyclops confinis & $88(0.5 \%)$ \\
\hline & & & Afrocyclops gibsoni & $75(0.4 \%)$ \\
\hline & & & Halicyclops sp. & $45(0.3 \%)$ \\
\hline & & & Microcyclops varicans & $58(0.3 \%)$ \\
\hline & & & Phyllognatopus sp. & $97(0.5 \%)$ \\
\hline & & \multirow{2}{*}{ Larval stage } & Nauplii & $7419(42.3 \%)$ \\
\hline & & & Copepodits & $7388(42.1 \%)$ \\
\hline \multirow{2}{*}{ Malacostraca } & \multirow{2}{*}{ Decapoda } & \multirow{2}{*}{ Atyidae } & Caridina africana & $2239(86.5 \%)$ \\
\hline & & & Caridina nilotica & $349(13.5 \%)$ \\
\hline Insecta & Diptera & Chironomidae & Chironomus sp. & $5212(100 \%)$ \\
\hline \multirow{2}{*}{ Gasteropoda } & \multirow{2}{*}{ Basommatophora } & \multirow{2}{*}{ Physidae } & Aplexa sp. & $1553(8.6 \%)$ \\
\hline & & & Physa acuta & $16502(91.4 \%)$ \\
\hline
\end{tabular}

cerning Copepoda, a total of 17,555 individuals were counted in the two river basins during the study period. The larvae Nauplii and Copepodits dominated the Copepod's community with respectively $42.3 \%$ and $42.1 \%$ of total abundances, follow by the species Mesocyclops sp. (7.5\%), Allocyclopina sp. (3.1\%), Eucyclops serrulatus (2.0\%), Thermocyclops sp. (1.0\%), Tropocyclops confinis (0.5\%), Phyllognatopus sp. (0.5\%), Afrocyclops gibsoni (0.4\%), Halicyclops sp.(0.3\%) and Microcyclops varicans (0.3\%) (Table 4).

In the Sanaga river basin, the highest relative abundances of $C$. africana and $C$. nilotica were obtained in stations S1 (36.18\% and 31.86\% respectively) and S2 (38.35\% and $31.54 \%$ respectively) while in the Wouri watershed, the maximum number of individuals were registered in the station WO $(88.61 \%$ for $C$. africana and $87.50 \%$ for C. nilotica); no freshwater shrimp species was present in stations $\mathrm{MB}, \mathrm{MG}$ and MP all over the study period (Table 5). Concerning Diptera-Chironomidae, the highest relative abundances of Chironomus sp. were observed in stations M2 (52.01\%) and M3 (35.11\%) in the river basin of Sanaga; whereas in the watershed of Wouri, the maximum number of individuals (26.01\%) was recorded in station LM (Table 5). Regarding Gasteropoda-Physidae, $P$. acuta and Aplexa sp. were dominant in stations M2 (39.40\% and 31.85\% respectively) and M3 (52.44\% and 62.99\% respectively) in the river basin of Sanaga. In the watershed of Wouri, abundances slightly varied from one station to another; highest abundances being observed at station WO (2.34\%) for P. acuta 
Table 5. Spatial dynamic of abundances (relative abundances) of different species of Atyidae, Chironomidae and Physidae identified during the study period.

\begin{tabular}{|c|c|c|c|c|c|c|}
\hline \multirow{2}{*}{$\begin{array}{l}\text { River } \\
\text { basins }\end{array}$} & \multirow{2}{*}{$\begin{array}{l}\text { Sampling } \\
\text { stations }\end{array}$} & \multicolumn{2}{|c|}{ Atyidae } & \multirow{2}{*}{$\begin{array}{l}\text { Chironomidae } \\
\text { Chironomus sp. }\end{array}$} & \multicolumn{2}{|c|}{ Physidae } \\
\hline & & Caridina africana & Caridina nilotica & & Aplexa sp. & Physa acuta \\
\hline \multirow{9}{*}{ 总 } & $\mathrm{B} 1$ & $72(5.39 \%)$ & $9(2.84 \%)$ & $40(1.87 \%)$ & $0(0.00 \%)$ & $12(0.03 \%)$ \\
\hline & $\mathrm{B} 2$ & $37(2.77 \%)$ & $6(1.89 \%)$ & $31(1.45 \%)$ & $1(0.01 \%)$ & $27(0.07 \%)$ \\
\hline & B3 & $31(2.32 \%)$ & $0(0.00 \%)$ & $26(1.22 \%)$ & $3(0.05 \%)$ & $18(0.04 \%)$ \\
\hline & M1 & $69(5.17 \%)$ & $1(0.03 \%)$ & $48(2.24 \%)$ & $25(4.44 \%)$ & $130(3.41 \%)$ \\
\hline & M2 & $65(4.87 \%)$ & $15(4.73 \%)$ & $1111(52.01 \%)$ & $179(31.85 \%)$ & $1504(39.40 \%)$ \\
\hline & M3 & $66(4.94 \%)$ & $85(26.81 \%)$ & $750(35.11 \%)$ & $354(62.99 \%)$ & $2002(52.44 \%)$ \\
\hline & S1 & $483(36.18 \%)$ & $101(31.86 \%)$ & $58(2.71 \%)$ & $0(0.00 \%)$ & $3(0.01 \%)$ \\
\hline & $\mathrm{S} 2$ & $512(38.35 \%)$ & $100(31.54 \%)$ & $72(3.37 \%)$ & $0(0.00 \%)$ & $121(3.17 \%)$ \\
\hline & Total & $1335(100 \%)$ & $317(100 \%)$ & $2136(100 \%)$ & $562(100 \%)$ & $3817(100 \%)$ \\
\hline \multirow{9}{*}{$\frac{1}{3}$} & $\mathrm{KO}$ & $42(4.64 \%)$ & $1(3.13 \%)$ & $407(13.23 \%)$ & $131(13.21 \%)$ & $2845(22.43 \%)$ \\
\hline & LM & $45(4.98 \%)$ & $3(9.37 \%)$ & $800(26.01 \%)$ & $601(60.64 \%)$ & $2088(16.46 \%)$ \\
\hline & $\mathrm{MB}$ & $0(0.00 \%)$ & $0(0.00 \%)$ & $471(15.31 \%)$ & $7(0.07 \%)$ & $2076(16.36 \%)$ \\
\hline & MG & $0(0.00 \%)$ & $0(0.00 \%)$ & $22(0.07 \%)$ & $110(11.10 \%)$ & $2356(18.57 \%)$ \\
\hline & MP & $0(0.00 \%)$ & $0(0.00 \%)$ & 367 (11.93\%) & $7(0.07 \%)$ & $1057(8.33 \%)$ \\
\hline & TB & $3(0.03 \%)$ & $0(0.00 \%)$ & $464(15.08 \%)$ & $105(10.59 \%)$ & $1163(9.17 \%)$ \\
\hline & TW & $13(1.44 \%)$ & $0(0.00 \%)$ & $467(15.18 \%)$ & $24(0.24 \%)$ & $803(6.33 \%)$ \\
\hline & WO & $801(88.61 \%)$ & $28(87.50 \%)$ & $78(2.54 \%)$ & $6(0.06 \%)$ & $297(2.34 \%)$ \\
\hline & Total & $904(100 \%)$ & $32(100 \%)$ & $3076(100 \%)$ & $991(100 \%)$ & $12,685(100 \%)$ \\
\hline
\end{tabular}

and station LM (60.64\%) for Aplexa sp (Table 5).

Concerning Copepods, Mesocyclops sp. was the most represented species both in the Sanaga and Wouri watershed, with higher relative abundance observed in stations B3 (33.78\%) and KO (73.03\%). The species Allocyclopina sp., Eucyclops serrulatus and Thermocyclops sp. were also well represented. Nevertheless, the lowest relative abundances of these species were observed in stations M2 and M3 (Table 6). The t-test of Student revealed that mean abundance of copepods was significantly high $(\mathrm{P}=0.003)$ in the river basin of Sanaga compared to Wouri watershed.

\subsection{Spatial and Temporal Dynamic of Taxa Densities}

Spatial and temporal variation of invertebrate densities revealed that in the Sanaga river basin, high densities of freshwater shrimps of the family Atyidae were obtained at stations S1 in June $\left(145\right.$ ind. $\left./ \mathrm{m}^{2}\right)$ and S2 in July (147 ind./m²) (Figure $1(\mathrm{a})$ ); while in the watershed of Wouri these densities were globally high in station WO with maximum value observed in June (186 ind./m²) (Figure 1(b)).

One way ANOVA test showed that densities of Atyidae significantly varied ( $\mathrm{P}$ $=0.0001$ ) from one station to another, values recorded in stations S1, S2 and WO being significantly higher (Banferroni, $\mathrm{P}<0.05$ ) compared to the other 
Table 6. Spatial dynamic of abundances (relative abundances) of larvae and different species of copepods identified during the study period.

\begin{tabular}{|c|c|c|c|c|c|c|c|c|c|c|c|c|}
\hline \multirow[b]{2}{*}{ 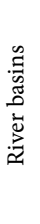 } & \multirow[b]{2}{*}{ 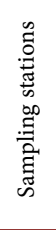 } & \multicolumn{9}{|c|}{ Cyclopidae } & \multicolumn{2}{|c|}{ Larval stage } \\
\hline & & 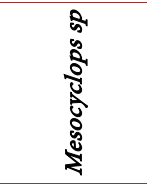 & 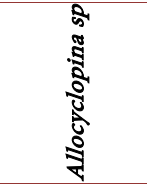 & 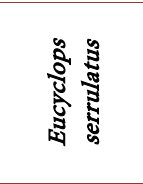 & 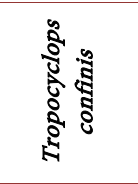 & 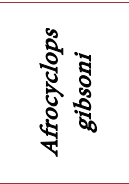 & 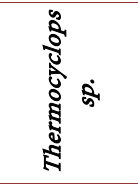 & 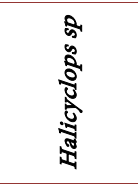 & 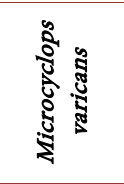 & 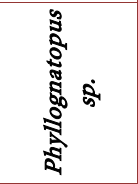 & 流 & 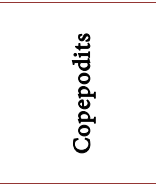 \\
\hline \multirow{8}{*}{ 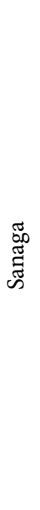 } & B1 & $53(5.92 \%)$ & $47(13.58 \%)$ & $20(9.30 \%)$ & $8(13.11 \%)$ & $7(13.73 \%)$ & $19(12.93 \%)$ & $7(26.92 \%)$ & $5(23.81 \%)$ & $1(1.72 \%)$ & $302(5.30 \%)$ & $299(5.80 \%)$ \\
\hline & B2 & $156(17.44 \%)$ & $46(13.29 \%)$ & $11(5.12 \%)$ & $4(6.56 \%)$ & $3(5.88 \%)$ & $10(6.80 \%)$ & $4(15.38 \%)$ & $1(4.76 \%)$ & $2(3.45 \%)$ & $723(12.70 \%)$ & $396(7.68 \%)$ \\
\hline & B3 & $302(33.78 \%)$ & $34(9.83 \%)$ & 37 (17.21\%) & $6(9.84 \%)$ & $16(31.37 \%)$ & $14(9.52 \%)$ & $2(7.69 \%)$ & $2(9.52 \%)$ & $1(1.72 \%)$ & $1771(31.10 \%)$ & $1042(20.21 \%)$ \\
\hline & M1 & $2(0.22 \%)$ & $1(0.02 \%)$ & $1(0.05 \%)$ & $1(1.64 \%)$ & $0(0.00 \%)$ & $1(0.07 \%)$ & $0(0.00 \%)$ & $0(0.00 \%)$ & $0(0.00 \%)$ & $7(0.01 \%)$ & $14(0.03 \%)$ \\
\hline & M2 & $37(4.14 \%)$ & $23(6.64 \%)$ & $10(4.65 \%)$ & $4(6.56 \%)$ & $4(7.84 \%)$ & $23(15.65 \%)$ & $2(7.69 \%)$ & $1(4.76 \%)$ & $3(5.17 \%)$ & $302(5.30 \%)$ & $657(12.74 \%)$ \\
\hline & S1 & $145(16.22 \%)$ & $101(29.19 \%)$ & $23(10.70 \%)$ & $9(14.75 \%)$ & $12(23.53 \%)$ & 47 (31.97\%) & $0(0.00 \%)$ & $0(0.00 \%)$ & $43(74.14 \%)$ & 997 (17.51\%) & $1034(20.06 \%)$ \\
\hline & S2 & $132(14.76 \%)$ & $12(3.35 \%)$ & $101(46.98 \%)$ & $23(37.70 \%)$ & $7(13.73 \%)$ & $12(8.16 \%)$ & $9(35.62 \%)$ & $9(42.85 \%)$ & $8(13.79 \%)$ & $1001(17.58 \%)$ & $1022(20 \%)$ \\
\hline & Total & $894(100 \%)$ & $346(100 \%)$ & $215(100 \%)$ & $61(100 \%)$ & $51(100 \%)$ & $147(100 \%)$ & $26(100 \%)$ & $21(100 \%)$ & $58(100 \%)$ & $5694(100 \%)$ & $5155(100 \%)$ \\
\hline \multirow{8}{*}{$\begin{array}{l}\vec{\Xi} \\
\overline{3}\end{array}$} & $\mathrm{KO}$ & $301(73.06 \%)$ & $134(68.02 \%)$ & 97 (75.19\%) & $3(11.11 \%)$ & $12(50.00 \%)$ & $9(25.00 \%)$ & $1(5.26 \%)$ & $2(5.41 \%)$ & $2(5.13 \%)$ & $1031(59.77 \%)$ & $1223(54.77 \%)$ \\
\hline & LM & $3(0.07 \%)$ & $1(0.05 \%)$ & $1(0.08 \%)$ & $1(3.70 \%)$ & $1(4.17 \%)$ & $1(2.78 \%)$ & $0(0.00 \%)$ & $0(0.00 \%)$ & $0(0.00 \%)$ & 33 (1 ?91\%) & $84(3.76 \%)$ \\
\hline & $\mathrm{MB}$ & $0(0.00 \%)$ & $0(0.00 \%)$ & $0(0.00 \%)$ & $0(0.00 \%)$ & $0(0.00 \%)$ & $0(0.00 \%)$ & $0(0.00 \%)$ & $0(0.00 \%)$ & $0(0.00 \%)$ & $1(0.001 \%)$ & $3(0.01 \%)$ \\
\hline & MG & $2(0.05 \%)$ & $0(0.00 \%)$ & $0(0.00 \%)$ & $0(0.00 \%)$ & $0(0.00 \%)$ & $0(0.00 \%)$ & $0(0.00 \%)$ & $0(0.00 \%)$ & $0(0.00 \%)$ & $23(1.33 \%)$ & $10(0.01 \%)$ \\
\hline & MP & $1(0.02 \%)$ & $1(0.05 \%)$ & $0(0.00 \%)$ & $0(0.00 \%)$ & $0(0.00 \%)$ & $0(0.00 \%)$ & $0(0.00 \%)$ & $0(0.00 \%)$ & $0(0.00 \%)$ & $3(0.02 \%)$ & $13(0.04 \%)$ \\
\hline & TB & $0(0.00 \%)$ & $1(0.05 \%)$ & $0(0.00 \%)$ & $0(0.00 \%)$ & $0(0.00 \%)$ & $0(0.00 \%)$ & $0(0.00 \%)$ & $1(2.70 \%)$ & $0(0.00 \%)$ & $11(0.06 \%)$ & $17(0.07 \%)$ \\
\hline & WO & $77(18.70 \%)$ & $43(21.82 \%)$ & $22(17.05 \%)$ & $22(81.48 \%)$ & $9(37.50 \%)$ & $24(66.67 \%)$ & $10(52.63 \%)$ & $\begin{array}{c}33 \\
(89.19 \%)\end{array}$ & $34(87.18 \%)$ & $556(32.23 \%)$ & $730(32.69 \%)$ \\
\hline & Total & $421(100 \%)$ & 197 (100\%) & $129(100 \%)$ & $27(100 \%)$ & $24(100 \%)$ & $36(100 \%)$ & $19(100 \%)$ & $37(100 \%)$ & $39(100 \%)$ & $1725(100 \%)$ & $2233(100 \%)$ \\
\hline
\end{tabular}

sampling stations in the Sanaga river basin. Concerning Copepods, higher densities were registered at stations B3 in June (848 ind./L) and KO in May (760 ind./L). These densities were globally high during the over flood period (Figure 1(c) and Figure 1(d)). Densities of Copepoda increase significantly (ANOVA, P $=0.009$ ) during the over flood period in all sampling stations of the Sanaga watershed. However, monthly variations of these densities were not significant in the Wouri river basin (ANOVA, $\mathrm{P}=0.38$ ). The spatial variation of the Copepods densities was significant, with values recorded at station WO being significantly different from those registered in stations MG, MP and TB (Banferroni, $\mathrm{P}<$ $0.05)$. In the same way, values recorded at station $\mathrm{KO}$ were significantly different from those registered in stations MG, MP and TB (Banferroni, $\mathrm{P}<0.05$ ).

As for Chironomidae, densities varied from 0 to $199 \mathrm{ind} . / \mathrm{m}^{2}$, the highest value being obtained in station M2 in October (Figure 2(a)). In the Wouri river basin, Chironomidae densities relatively varied from one month to another, higher values being recorded at station LM in February $\left(195 \mathrm{ind} . / \mathrm{m}^{2}\right)$. Stations KO and TW also present higher densities during the month of February (Figure 2(b)); 


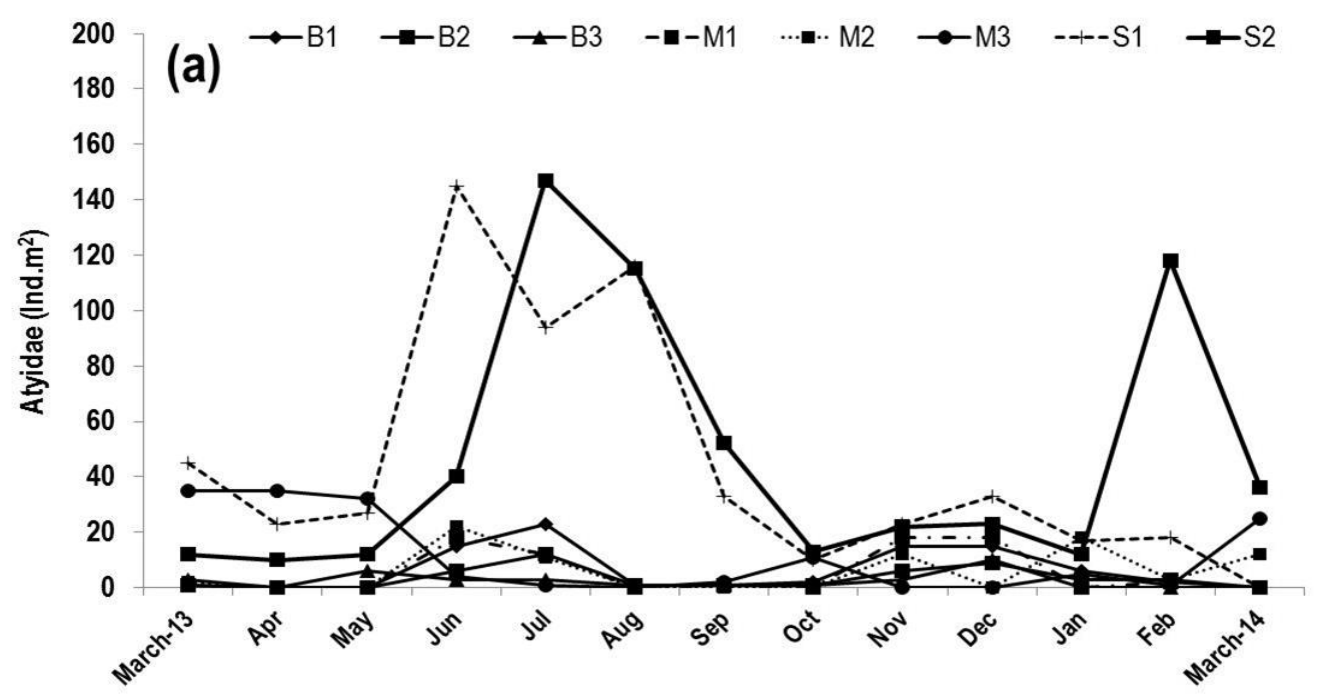

Months
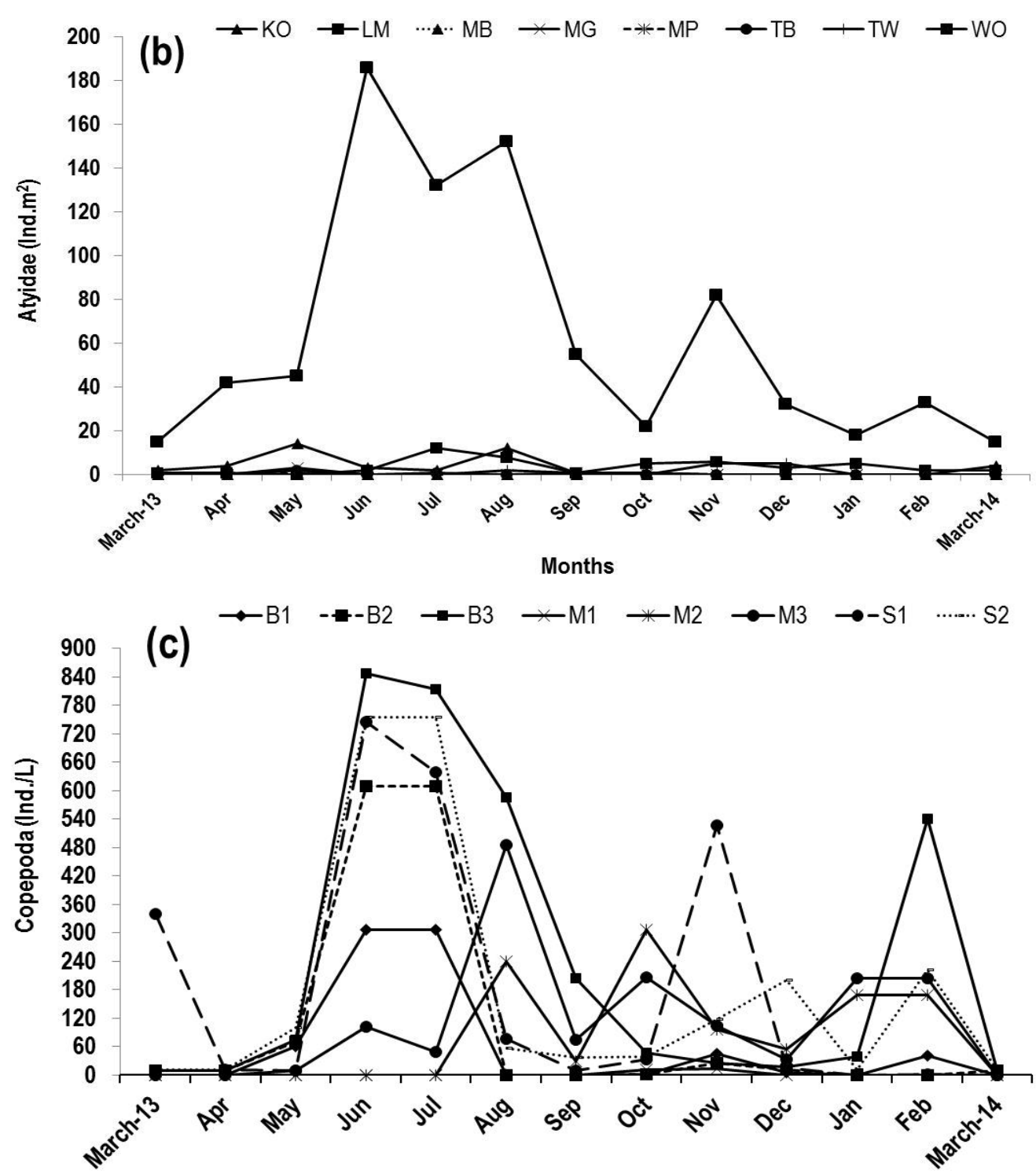

Months 


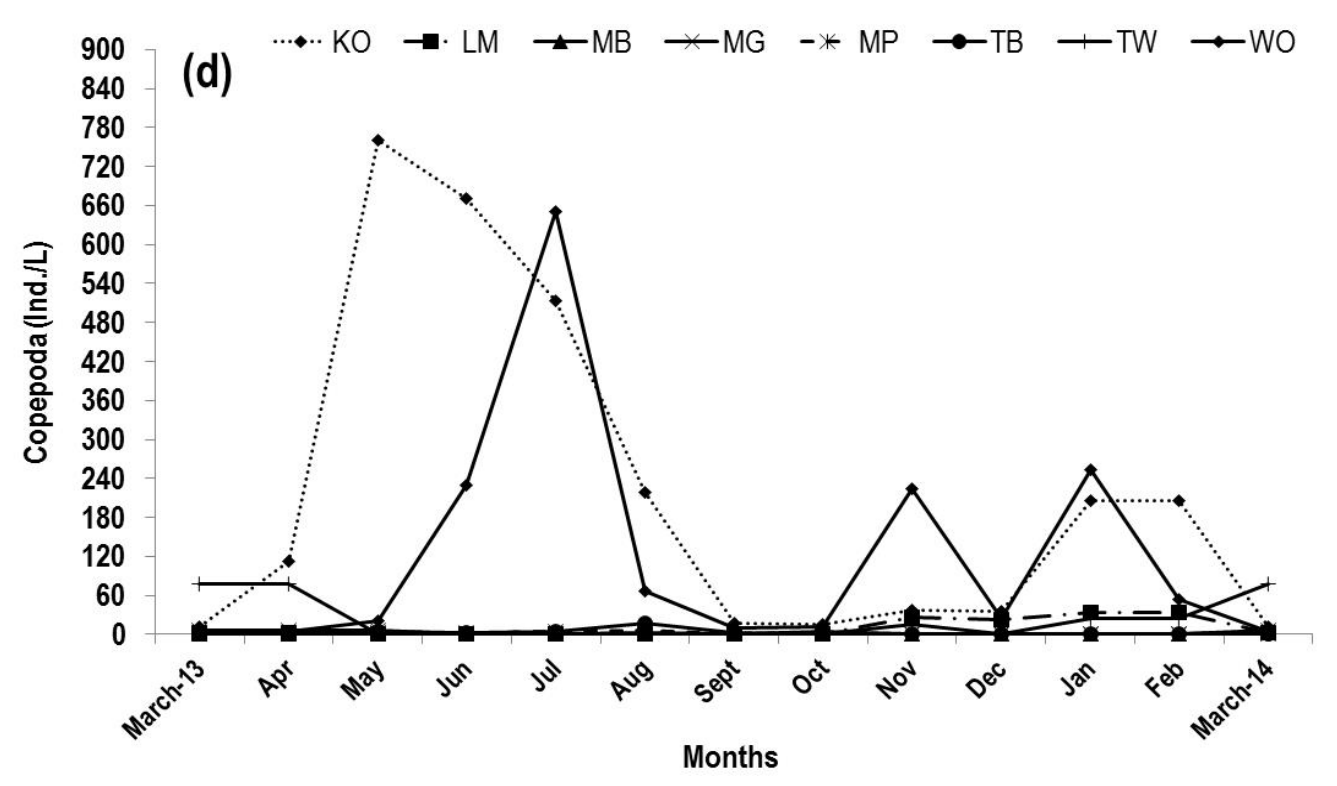

Figure 1. Spatial and temporal variations of Atyidae and Copepod's densities in Sanaga ((a) and (c)) and Wouri ((b) and (d)) rivers basins.

while in station $\mathrm{TB}$, the maximum density was registered in March. The spatial variation of Chironomidae densities was significant in the Sanaga river basin (ANOVA, $\mathrm{P}=0.001$ ), with mean values obtained at stations M2 and M3 being significantly higher (Banferroni, $\mathrm{P}<0.05$ ). In the Wouri river basin, densities of Chironomidae were significantly low in station WO (Banferroni, $\mathrm{P}<0.05$ ). In the Sanaga watershed, the Physidae densities were low from March to November and started increase in December, with the highest value $\left(707\right.$ ind. $\left./ \mathrm{m}^{2}\right)$ being obtained at station M2 in December (Figure 2(c)). In the same way, these densities slightly fluctuated between March and August, with higher values being observed from September to March (Figure 2(d)). Furthermore, in Edea sampling sites, Physidae were statistically dominant at stations M2 and M3 during the study (Banferroni, $\mathrm{P}<0.05$ ). The spatial and temporal variations of Physidae densities were not significant in the river basin of Wouri (ANOVA, $\mathrm{P}<0.05$ ). Thus, for the Physidae densities, no significant difference were detected between sampling sites located in Edea and Douala ( $\mathrm{t}$-student, $\mathrm{P}=0.06$ ).

\subsection{Relationships between Environmental Factors and Abundance Dynamic of Invertebrates}

The results of the first principal component analysis (PCA) based on the spatial gathering of parameters, revealed that the relationship between invertebrate densities and abiotic factors follows mainly the first two axes (D1 $=41.48 \%$; D2 $=31.52 \%$ ) which accounted for $73.00 \%$ of the total variance expressed. The distribution of observations on the factor plan is separated into two groups (I and II) (Figure 3(a)).

The first group (I) is constituted of parameters such as electrical conductivity, color, oxydability, salinity, suspended solids, dissolved carbon dioxide and water temperature which are positively correlated with the Physidae and Chironomi- 

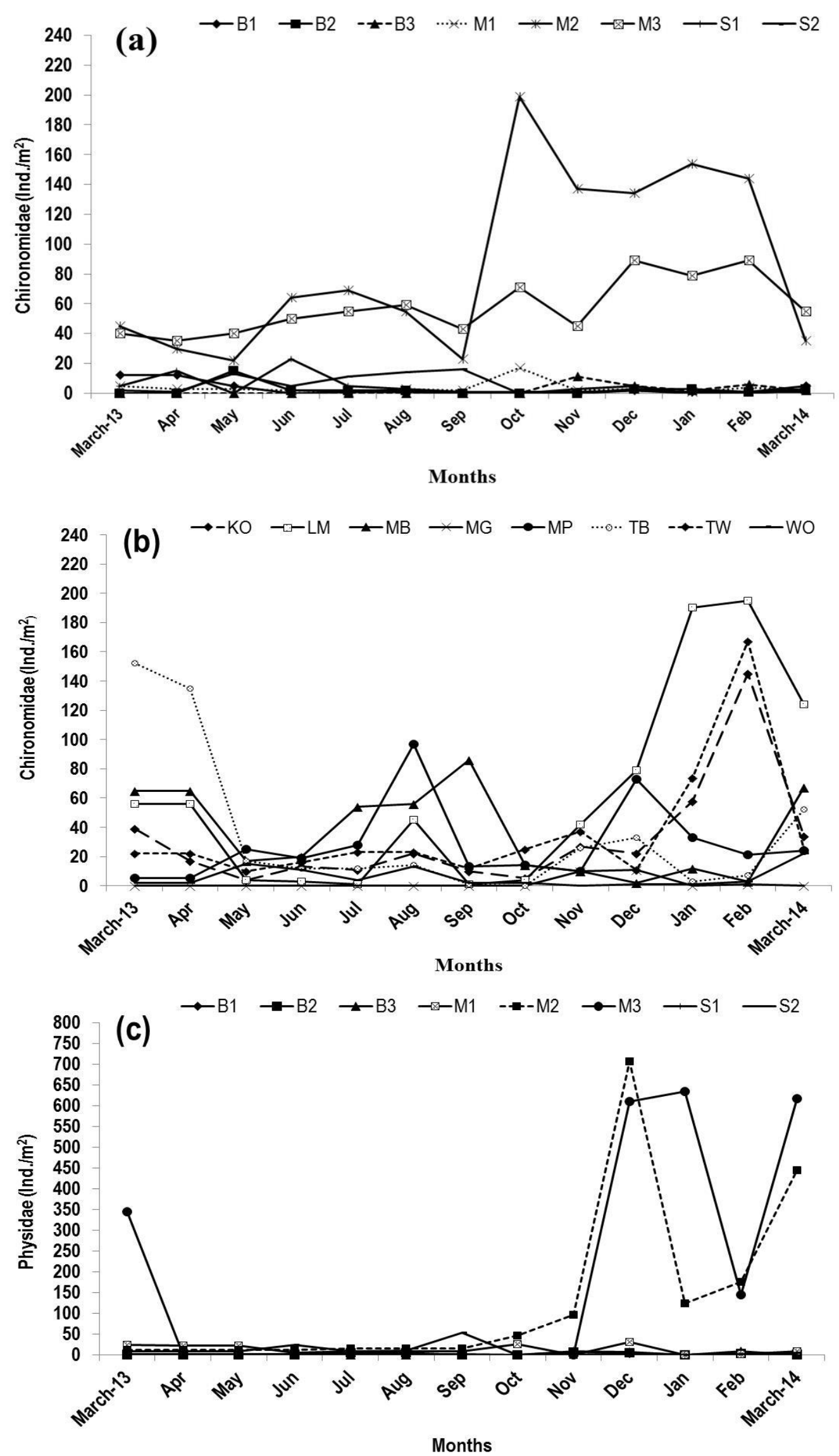


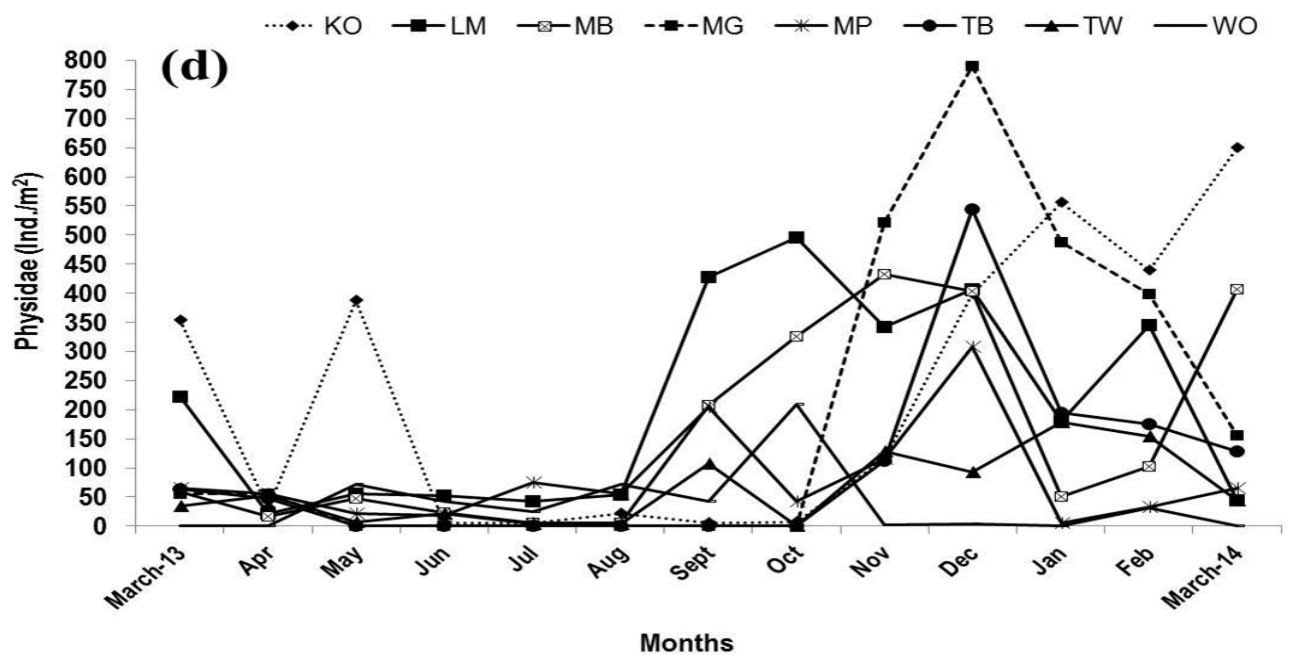

Figure 2. Spatial and temporal variations of Chironomidae and Physidae densities in Sanaga ((a) and (c)) and Wouri ((b) and (d)) river basins
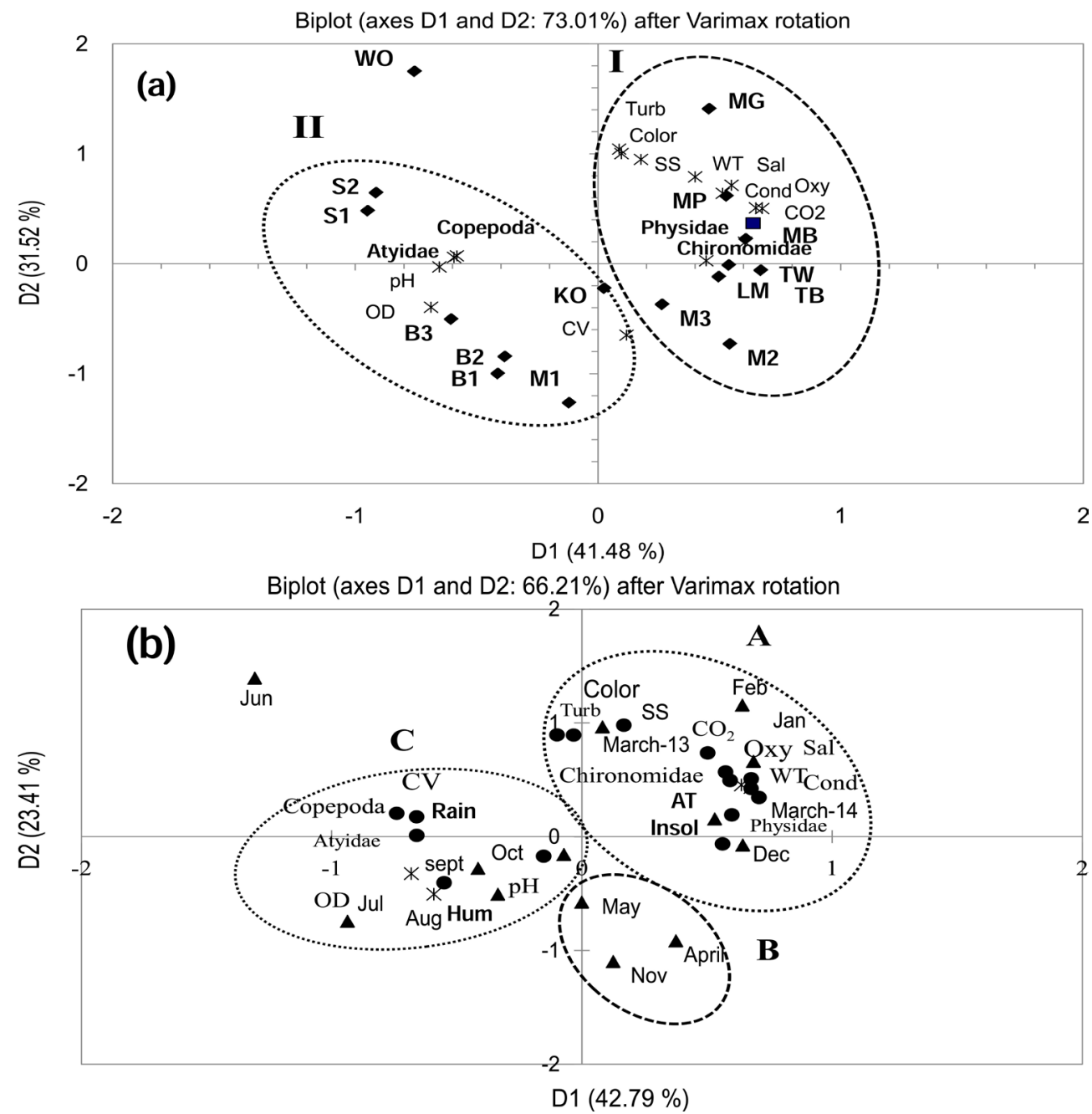

Figure 3. Principal component analysis showing spatial (a) and temporal (b) gathering of aquatic invertebrates in response to environmental factors $\left(\mathrm{Oxy}=\right.$ oxydability, $\mathrm{WT}=$ water temperature, $\mathrm{CO}_{2}=$ dissolved carbon dioxide, $\mathrm{Sal}=$ salinity, Cond $=$ conductivity, $\mathrm{OD}=$ oxygen dissolved, $\mathrm{SS}=$ suspended solids, Turb $=$ turbidity, $\mathrm{CV}=$ current velocity, Rain = rains, $\mathrm{AT}=$ air temperature, Hum = relative humidity, $\mathrm{Insol}=$ insolation). 
dae densities. These parameters are characteristic of the stations located in urban area of Douala (MG, MP, MB, TB, TW and LM) and Edea (M2 and M3) which are highly subjected to organic pollution. The second group (II) is made up of parameters such as dissolved oxygen, $\mathrm{pH}$ and current velocity which are associated with the Copepods and Atyidae densities. These variables are characteristic of suburban stations of Edea (S1, S2, B1, B2 and B3) and the marshy station $\mathrm{KO}$ of the Wouri basin. These stations are less subjected to anthropogenic disturbances and have relatively good water quality.

The results of the second principal component analysis (PCA) based on the temporal (month) gathering of parameters, revealed that the relationship between invertebrate densities and abiotic factors follows mainly the first two axes (D1 $=42.79 \%$; D2 $=23.41 \%)$ which accounted for $66.20 \%$ of the total variance expressed. The distribution of observations on the factor plan is separated into three groups (A, B and C) (Figure 3(b)).

Group A is constituted of parameters such as color, turbidity, suspended solids, dissolved carbon dioxide, oxydability, salinity, water temperature, electrical conductivity, air temperature and insolation which are positively correlated with the Physidae and Chironomidae densities. This association is more pronounced during the months of December, January, February and March, which are characterized by low water level and hydrous stress. Group B gathered the months of April, May and November which presented relatively the same abiotic factors. This low water flow period seem not to significantly influence the distribution of aquatic invertebrates. Group $\mathrm{C}$ is constituted of parameters such as current velocity, dissolved oxygen, $\mathrm{pH}$, relative wetness and rainfalls which are positively correlated with the Copepda and Atyidae densities. This association is more pronounced during the months of June, July, August and September, which are characterized by over flood.

\section{Discussion}

\subsection{Characteristic of Environmental Variables}

The analysis of meteorological parameters of the littoral region of Cameroon permitted to determine three periods: a low flood period (April, May, October and November), a low water level period (December, January, February and March) and an over flood period (June, July and September). This variability might be due to anthropogenic activities, influence of Atlantic Ocean and global climate change. Similar results were documented in Equatorial Central Africa on the variability of the hydrographic regime [26] [27]. The strong correlation observed between rainfalls and relative wetness shows that the atmosphere of these zones, does not exchange only heat with the ocean, but also of water vapor and rains. Indeed, littoral water system such as marshy and lake maintain a high relative wetness all over the year. This observation is online with the work of Drijfhout et al. [28] on climate variability. Furthermore, negatively significant correlation recorded between rainfalls and current velocity revealed the impact of seasonal variability on the hydrological and even the ecological regime of wa- 
ter. Our results are closer to those of Diomandé [29] on some Ivorian rivers and Tchakonté et al. [10] on some urban rivers in Douala Cameroon.

Concerning physicochemical parameters measured the slightly high values of water temperature registered in Douala watershed should be related to urbanization, anarchical land used and the anthropogenic activities in this township. Indeed, in this situation water systems are subjected to light rays and industrials wastes. Our results are consistent with the work carry out Tchakonté et al. [30]. Although the impact of anthropogenic activities is perceptible on the heat flux, these values of water temperature remain in the optimal range for the development of aquatic organisms [8] [31] [32]. Furthermore, the increase of temperature in stations M2 and M3 would have favored the degradation of organic matter, which thus increase the electrical conductivity and reduce the oxygen content these stations. Similar results were documented for other Cameroonian rivers surface [10] [33]. High values of oxydability in stations M2 and M3 should be due to urban and industrials wastes. Inversely, low values of these parameters observed in stations B1, B2, B3, M1, M2, S1 and S2 could be due to the absence of houses and industries. These observations are consistent with the results documented by Tchakonté et al. [10] in urban and suburban streams of Douala. On the other hand, the significantly high values of oxydability in Douala watershed reflect the important input of domestic and industrial wastes. This conclusion is concomitant with that outlet by Onana et al. [34] on the stream Kondi in Douala.

High values of suspended solids observed during the beginning of the rainy season, could be due to the input of various matters by storm water drainage. Moreover, high tide induces the increase of suspended solids in the coastal rivers [35]. Similar observations were done by Diomandé [29] on the Agnéby River in Ivory Coast. The relatively high values of salinity in Douala watershed may be related to the high concentration of minerals due to anthropogenic disturbances. Nevertheless, the significantly high values of salinity registered in Wouri river are surely linked to the contamination by brackish waters.

\subsection{Influence of Environmental Factors on the Abundance Dynamic of Invertebrates}

The families of Physidae and Chironomidae were more abundant in urban stations than in stations situated in suburban area, especially during low water level period, showing that they are well adapted to anthropogenic and organic pollutions. They are known to be saprophagous [36]. The prolificness of the nonbiting midges Chironomidae is not surprising, because they are opportunists and tolerant of polluted waters where they may occur in large numbers [36] [37]. Indeed, Chironominae are known as 'blood worms' because they are bright red, due to the presence of hemoglobin in their body fluids that enables them to respire at low oxygen concentrations and live in hypoxic or occasional anoxic bottom mud [10] [37] [38]. Moreover, they can build inter-connected galleries in mud, which are then ventilated by undulatory movements; or they can prolong 
their tubes above the surface of the sediment to capture oxygen molecules [39] [40]. As such, the well adaptation of Physidae to harsher conditions may be due to the fact that their shell is a physical barrier to pollutants, and they are also able to assimilate atmospheric air via a vascularized mantle cavity [3] [41].

The hypoxic conditions of urban waterways do not favor the proliferation of sensitive taxa such as Atyidae and Copepda. These taxa preferred well oxygenated waters with rapid flow, and are more abundant during rainy season in stations located in suburban area or which are less subjected to anthropogenic disturbances. Similar results are recorded in other Cameroonian streams, revealing that freshwater shrimps Atyidae proliferate in well oxygenated rivers [12] [30]. In the same way, Mergeay et al. [42] noted a significant increase in the density of Copepoda in surface water during flood. Atyidae and Copepda organisms seem to be very sensitive to the variations of the organic matter loads and dissolved oxygen content.

\section{Conclusion}

This study highlights that the abundance dynamics of freshwater invertebrates in the watersheds of Douala and Edea are highly influenced by water pollution due to anthropogenic disturbances. On the one hand, input of organic matter induce the installation and the prolificness of resistant taxa such as Physidae and Chironomidae, which are well adapted to organic pollution and hypoxic condition of the medium. On the other hand, water pollution causes the fled and the extinction sensitive taxa such as Decapoda-Atyidae and Crustacea-Copepoda, which are very sensitive to oxygen content depletion and rainfalls variability. These ecological characteristics might be used to increase the preciseness of water quality assessment methodologies of biomonitoring programs. There is therefore, the need for an elaborate characterization of wastewaters and water bodies, and the evaluation of treatment facilities of municipal waste so as to assess the status and control water pollution.

\section{References}

[1] Walsh, C.J., Sharpe, A.K., Breen, P.F. and Sonneman, J.A. (2001) Effects of Urbanization on Streams of the Melbourne Region, Victoria, Australia. I. Benthic Macroinvertebrate Communities. Freshwater Biology, 46, 535-551. https://doi.org/10.1046/j.1365-2427.2001.00690.x

[2] Faria, M.S., Nogueira, A.J. and Soares, A.M. (2007) The Use of Chironomus riparius Larvae to Assess Effects of Pesticides from Rice Fields in Adjacent Freshwater Ecosystems. Ecotoxicology and Environmental Safety, 67, 218-226.

[3] Tchakonte, S., Ajeagah, G.A., Diomande, D., Camara, A.I. and Ngassam, P. (2014) Diversity, Dynamic and Ecology of Freshwater Snails Related to Environmental Factors in Urban and Suburban Streams in Douala-Cameroon (Central Africa). Aquatic Ecology, 48, 379-395. https://doi.org/10.1007/s10452-014-9491-2

[4] Bass, D. and Potts, C. (2001) Invertebrate Community Composition and Physicochemical Conditions of Boehler Lake, Atoka County, Oklahoma. Proceedings of the Oklahoma Academy of Science, 81, 21-29.

[5] Rios, S.L. and Bailey, R.C. (2006) Relationship between Riparian Vegetation and 
Stream Benthic Communities at Three Spatial Scales. Hydrobiologia, 553, 153-160. https://doi.org/10.1007/s10750-005-0868-Z

[6] Zhong, Y., Nellimoottil, T., Peace, J.M., Knott, S.R., Villwock, S.K., Yee, J.M., Jancuska, J.M., Rege, S., Tecklenburg, M., Sclafani, R.A., Tavare, S. and Aparicio, O.M. (2013) The Level of Origin Firing Inversely Affects the Rate of Replication Fork Progression. The Journal of Cell Biology, 201, 373-83.

https://doi.org/10.1083/jcb.201208060

[7] BenMoussa, A., Chahlaoui, A., Rour, E. and Chahboune, M. (2014) Taxonomic Diversity and Structure of Benthic Macrofauna of Surface Water of Khoumane River, Moulay Idriss Zerhoun, Morocco. Journal of Materials and Environmental Science, 5, 183-198. http://www.jmaterenvironsci.com

[8] Tchakonté, S. (2016) Diversité et structure des peuplements de macroinvertébrés benthiques des cours d'eau urbains et périurbains de Douala (Cameroun). Thèse de Doctorat/PhD, Université de Yaoundé.

[9] Moisan, J. and Pelletier, L. (2008) Guide de surveillance biologique basée sur les macroinvertébrés benthiques d'eau douce du Québec-cours d'eau peu profonde à substrat grossier. Direction de Suivi de l'Etat de l'Environnement, Ministère du Développement Durable de l'Environnement et des Parcs.

[10] Tchakonte, S., Ajeagah, G.A., Camara, A.I., Diomande, D., Nyamsi Tchatcho, N.L. and Ngassam, P. (2015) Impact of Urbanization on Aquatic Insect Assemblages in the Coastal Zone of Cameroon: The Use of Biotraits and Indicator Taxa to Assess Environmental Pollution. Hydrobiologia, 755, 123-144. https://doi.org/10.1007/s10750-015-2221-5

[11] Warrin, E., Din, Z.B. and Che Salmah, M.R. (2008) Use of Tropical Chironomid Larva (Diptera: Chironomidae) as Indicator Organism for Aquatic and Sediment Toxicity. Proceedings International Conference on Environmental Research and Technology, 25, 14-19.

[12] Foto, M.S., Koji, E., Ajeagah, G., Bilong Bilong, C.F. and Njiné, T. (2012) Impact of Dam Construction on the Diversity of Benthic Macroinvertebrates Community in a Periurban Stream in Cameroon. International Journal of Biosciences, 2, 137-145.

[13] Nyamsi Tchatcho, N.L., Foto Menbohan, S., Zébazé Togouet, S.H., Onana, F.M., Adandedjan, D., Tchakonté, S., Yémélé Tsago, C., Koji, E. and Njiné, T. (2014) Indice Multimétrique des Macroinvertébrés Benthiques Yaoundéens (IMMY) Pour L'évaluation Biologique de la Qualité des Eaux de Cours D'eau de la Région du Centre Sud Forestier du Cameroun. European Journal of Scientific Research, 123, 412-430.

[14] Moss, B. (1998) Ecology of Fresh Waters: Man and Medium, Past to Future. Blackwell Science, Oxford.

[15] Nziéleu Tchapgnouo, J.G., Njiné, T., Zébazé Togouet, S.H., Djutso Segnou, S.C., Mahamat Tahir, T.S., Tchakonté, S. and Pinel-Alloul, B. (2012)Diversité spécifique et abondance des communautés de copépodes, cladocères et rotifères des lacs du complexe Ossa (Dizangué, Cameroun). Physio-Géo, 6, 71-93.

https://doi.org/10.4000/physio-geo.2430

[16] Olivry, J.C. (1986) Fleuves et rivières du Cameroun, Colloques Monographies Hydrologiques ORSTOM N${ }^{\circ}$, Editions MES RES-ORSTOM, Paris.

[17] Asaah, V.A., Abimbola, A.F. and Suh, C.E. (2006) Heavy Metal Concentration and Distribution in Surface Soils of the Bassa Industrial Zone 1 Douala Cameroon. Arabian Journal for Science and Engineering, 3, 147-158.

[18] Dubreuil, P., Moreil, M. and Sechet, P. (1975) Comportement et interactions des paramètres physiques des petits bassins versants semi-arides et intertropicaux. Cah. 
Orstom, sér. Hydrol, 13, 13-36.

[19] American Public Health Association (APHA) (2005) Standard Methods for the Examination of Water and Wastewater. Washington DC.

[20] Rodier, J., Legube, B., Marlet N. and Brunet, R. (2009) L'analyse de l'eau. 9th Edition, DUNOD, Paris.

[21] Fernando, C.H. (2002) A Guide to Tropical Freshwater Zooplankton: Identification Ecology and Impact on Fisheries. Backhuys Publishers, Leiden.

[22] Macé, R., Marta, C., Garcia, J.C., Goma, J. and Armengol, J. (2005) The Zooplankton Community in a Small, Hypertrophic Mediterranean Reservoir (Foix Reservoir, NE Spain). Limnetica, 24, 275-294.

[23] Stark, J.D., Boothroyd, K.G., Harding, J.S., Maxted, J.R. and Scarsbrook, M.R. (2001) Protocols for Sampling Macroinvertebrates in Wadeable Streams. New Zealand Macroinvertebrates Working Group, Report, 1-57.

[24] Day, J.A., Harrison, A.D. and De Moor, I.J. (2002) Guides to the Freshwater Invertebrates of Southern Africa, Vol. 9: Diptera. Water Research Commission Report, No. TT 201/02, Pretoria.

[25] Stals, R. and De Moor, I.J. (2007) Guides to the Freshwater Invertebrates of Southern Africa, Vol. 10: Coleoptera. Water Research Commission Report, No. TT 320/07, Pretoria.

[26] Bricquet, J.P., Bamba, F., Mahé, G., Touré, M. and Olivry, J.-C. (1997) Évolution récente des ressources en eau de l'Afrique Atlantique. Revue des sciences de l'eau, 3, 321-337. https://doi.org/10.7202/705282ar

[27] Lienou, G., GIL Mahe, J.E., Pature, L., Servat, E., Sighomnou, D., Ekodeck, G.E., Dezetter, A. and Dieulin, C. (2008) Evolution des régimes hydrologiques en région équatoriale camerounaise: un impact de la variabilité climatique en Afrique équatoriale? Hydrological Sciences Journal, 53, 789-801.

https://doi.org/10.1623/hysj.53.4.789

[28] Drijfhout, S.S., Blaker, A.T., Josey, S.A., Nurser, A.J.G., Sinha, B. and Balmaseda, M.A. (2014) Surface Warming Hiatus Caused by Increased Heat Uptake across Multiple Ocean Basins. Geophysical Research Letters, 41, 7868-7874. https://doi.org/10.1002/2014GL061456

[29] Diomandé, D. (2001) Macrofaune benthique et stratégies alimentaires de Synodontysbatiani (Daget, 1948) et S, schall (Bloch \& Schneider, 1801) (Bassins Bia et Agnébi; Côte d'Ivoire). Thèse de Doctorat, Université d'Abobo-Adjamè (Abidjan).

[30] Tchakonté, S., Ajeagah, G., Diomandé, D., Camara, A.I., Konan, K.M. and Ngassam, P. (2014) Impact of Anthropogenic Activities on Water Quality and Freshwater Shrimps Diversity and Distribution in Five Rivers in Douala, Cameroon. Journal of Biodiversity and Environmental Sciences, 4, 183-194.

[31] Panfili, J., De Pontual, H., Troadec, J.-P. and Wright, P.J. (2002) Manual of Fish Sclerochronology. IFREMER-IRD Co-Edition, Brest.

[32] Moussa, B.A., Chahlaoui, A. and Rour El, H. (2013) Évaluation de la pollution physico-chimique des eaux de l'Oued Khoumane (Moulay Idriss Zerhoun, Maroc). International Journal of Biological and Chemical Sciences, 6, 7096-7111. https://doi.org/10.4314/ijbcs.v6i6.44

[33] Akindele, E.O. and Adeniyi, I.F. (2013) A Study of the Physicochemical Water Quality, Hydrology and Zooplankton Fauna of Opa Reservoir Catchment Area, Ile-Ife, Nigeria. African Journal of Environmental Science and Technology, 7, 192213. 
[34] Onana, F.M., Zebaze Togouet, S.H., Dassie Djiomo, B.S., Nna Samuel, C., Mvondo, N. and Ngassam, P. (2014) Impact de l'Effluent du Complexe Chimique Camerounais (CCC) sur la Structure du Peuplement de Macroinvertébrés Benthiques d'un Cours d'Eau Tropical Urbain (Douala, Cameroun). European Journal of Scientific Research, 121, 298-309.

[35] Guézennec, L., Dupont, J.P., Lafite, R., Meyer, R. and Goujou, R. (1996) Comportement hydrodynamique des suspensions dans la partie amont de l'estuaire de seine. Journal de Recherche Océanographique, 21, 53-58.

[36] Tachet, H., Richoux, P., Bournaud, M. and Usseglio-Polatera, P. (2010) Invertébrés d'eau douce. Systématique, biologie, écologie. CNRS éditions, Paris.

[37] Fanny,C., Archaimbault, V., Ferard, J.F., Bouquerel, J., Roger, M.C. and Devin, S. (2013) Benthic Indicators of Sediment Quality Associated with Run-of-River Reservoirs. Hydrobiologia, 703, 149-164. https://doi.org/10.1007/s10750-012-1355-y

[38] Failla, A.J., Vasquez, A.A., Fujimoto, M. and Ram, J.L. (2015) The Ecological, Economic and Public Health Impacts of Nuisance Chironomids and Their Potential as Aquatic Invaders. Aquatic Invasions, 10, 1-15. https://doi.org/10.3391/ai.2015.10.1.01

[39] Konstantinov, A.S. (1971) Feeding Habits of the Chironomid Larvae and Certain Ways to Increase the Food Content of the Water Basins. Manuscript Report Series (Fisheries Research Board of Canada), No. 1853.

[40] Gingras, M.K., Lalond, S.V., Amskold, L. and Konhauser, K.O. (2007) Wintering Chironomids Mine Oxygen. Palaios, 22, 433-438.

https://doi.org/10.2110/palo.2006.p06-036r

[41] Pedro, J., Rodolfo, A.C. and Marcelo, L.R. (1997) Behavior of Biomphalaria glabrata Say, 1818 (Gastropoda: Planorbidae)-I. Morphophysiology of the Mantle Cavity. Memórias do Instituto Oswaldo Cruz, 92, 287-295. https://doi.org/10.1590/S0074-02761997000200026

[42] Mergeay, J., Declerck, S., Verschuren, D. and Meester, L. (2006) Daphnia Community Analysis in Shallow Kenyan Lakes and Ponds Using Dormant Eggs in Surface Sediments. Freshwater Biology, 51, 399-411. https://doi.org/10.1111/j.1365-2427.2005.01494.x

Scientific Research Publishing

\section{Submit or recommend next manuscript to SCIRP and we will provide best service for you:}

Accepting pre-submission inquiries through Email, Facebook, LinkedIn, Twitter, etc. A wide selection of journals (inclusive of 9 subjects, more than 200 journals)

Providing 24-hour high-quality service

User-friendly online submission system

Fair and swift peer-review system

Efficient typesetting and proofreading procedure

Display of the result of downloads and visits, as well as the number of cited articles

Maximum dissemination of your research work

Submit your manuscript at: http://papersubmission.scirp.org/

Or contact jep@scirp.org 